\section{FELKÉSZÜLTÜNK A NYUGDÍJRA?}

Horváth Gyula (Aegon Magyarország, pénzügyi vezérigazgató-helyettes), horvath.gyula@aegon.hu

\section{ÖSSZEFOGLALÓ}

A cikk egy nemzetközi kutatás eredményeit ismerteti, melyet az Aegon Center for Longevity and Retirement, a Transamerica Center for Retirement Studies és a Cicero Consulting végzett el, és amelynek célja a nyugdíjjal kapcsolatos attitűdök, vélemények vizsgálata volt. A 15 országra kiterjedő vizsgálat fókuszában a nyugdíjfelkészültség állt. Az eredmények ismertetésén túl a szerző megkísérelte csoportosítani a részt vevő országokat a nyugdíjfelkészültség néhány mérőszáma alapján.

\section{SUMMARY}

The Aegon Center for Longevity and Retirement, the Transamerica Center for Retirement Studies and Cicero Consulting has conducted an international study about the attitudes and opinions regarding pension issues. The main subject of the 15-countries research was the retirement readiness. This article summarises the main findings and try to classify the countries based on some measures of retirement readiness.

\section{Kulcsszavak: nyugdíjtervezés, attitűdkutatás}

Key words: retirement plans, attitude research

\section{JEL: H55, J32}

DOI: $10.18530 /$ BK.2016.3.80

http://dx.doi.org/1018530/BK.2016.3.80

\section{Bevezetö}

Nem túlzás azt állítani, hogy a nyugdíjrendszer problémái, jövője ma a közgazdasági-pénzügyi gondolkodás egyik legfontosabb, legtöbbször tárgyalt kérdése Magyarországon (is). Csak az utóbbi egy évben számos tanulmány jelent meg a témában ${ }^{1}$, nem is beszélve a számtalan újságcikkről és tudósításról. Ezek általában a tényekkel foglalkoznak, a nyugdíjrendszer fenntarthatóságát, egyensúlyi helyzetét vagy a nyugdíjak eloszlását, az időskori szegénység problémáját vagy az ösztönzési kérdéseket vizsgálják. E tanulmány „szoftabb” megközelítésben vizsgálja a témát, a nyugdíjjal és a nyugdíjaskorral kapcsolatos attitüdökről szól. Alapja egy nemzetközi kutatás, melyet az Aegon Center for Longevity and Retirement, a Transamerica Center for Retirement Studies és a Cicero Consulting végzett el. A kutatás célja a nyugdífelkészültség vizsgálata a válaszolók szubjektív értékelése alapján.

\section{A kutatás módszertana}

A kutatás 15 országra terjedt ki, mindegyikben 900 munkavállalót és 100 nyugdíjast kérdeztek meg (Kína kivételével, ahol kétszeres mintát vettek), országonként reprezentatív mintán, online beszélgetés formájában. A vizsgált 15 ország:

- Ausztrália

- Brazília (csak városi lakosság)

- Egyesült Államok

- Egyesült Királyság

- Franciaország

- Hollandia

- India (csak városi lakosság)

- Japán

- Kanada

- Kína (csak városi lakosság)

- Lengyelország

- Magyarország

- Németország

- Spanyolország

- Törökország

A kutatást 5 éve végzik, kezdetben tíz országban (Egyesült Államok, Egyesült Királyság, Franciaország, Hollandia, Japán, Lengyelország, Magyarország, Németország, Spanyolország, Svédország), Svédország azonban 2015-ben kikerült a mintából. A megmaradt kilenc országra mint „eredeti országok”-ra hivatkozom a későbbiekben.

Az interjúkra 2016. február 6. és 25. között került sor. 


\section{A vizsgált problémakörök}

A kérdőív segítségével a következő főbb kérdéseket vizsgálták:

- Nyugdíjfelkészültség

- Az állam, a munkáltatók és az egyén szerepe a rendszer finanszírozásában, adózás és nyugdíjak, nyugdíjkorhatár és annak rugalmassága

- Megtakarítási hajlandóság

- Automatikus csatlakozás a nyugdíjprogramokhoz

- Egyéni nyugdíjstratégiák, a nyugdíjazás időpontja

- Mit várunk a nyugdíjaskortól?

\section{Nyugdíjfelkészültség}

A kutatásban hat kérdést tettek fel a munkavállalóknak a nyugdíjfelkészültséggel kapcsolatban.

- Milyen mértékben érzi személyes felelősségének, hogy nyugdíjas éveiben megfelelő jövedelemmel rendelkezzen? ( $1=$ nem vagyok felelős, $5=$ nagyon felelös vagyok)

- Hogyan értékelné a nyugdíjtervezés szükségességére irányuló ismereteit? ( $1=$ nagyon tudatlan, $5=$ nagyon tudatos)

- Mennyire érti meg a nyugdíjtervezéssel kapcsolatos pénzügyi fogalmakat? ( 1 = egyáltalán nem, $5=$ nagyon)

- A saját nyugdíjtervezésével kapcsolatban mennyire mondaná kialakultnak az egyéni nyugdijtervét? ( 1 = nincs tervem a nyugdíjra, $5=$ jól kialakított tervem van a nyugdíjra)

- Tudván, hogy mennyit tesz félre a nyugdíjára, ön szerint ez elégnek mondható? ( $1=$ alig teszek félre valamit, $5=$ már most is eleget teszek félre)

- Mit gondol arról, hogy el fogja-e érni a célként kitűzött nyugdíjat?

(1= nem tudom, hogy jó úton járok-e a nyugdíjcélom eléréséhez, 5= igen, jó úton járok, hogy elérjem a nyugdíjcélomat)

A kérdésekre adott válaszok megoszlása az 1. mellékletben található.

A válaszok alapján országonként és kérdésenként számolt számtani átlagok alapján kísérletet tettem az országok közötti hasonlóságok feltérképezésére klaszterelemzés segítségével ${ }^{2}$. Az elemzés dendrogrammját az 1. ábra tartalmazza.
1. ábra: Nyugdíj-felkészültségi országcsoportok

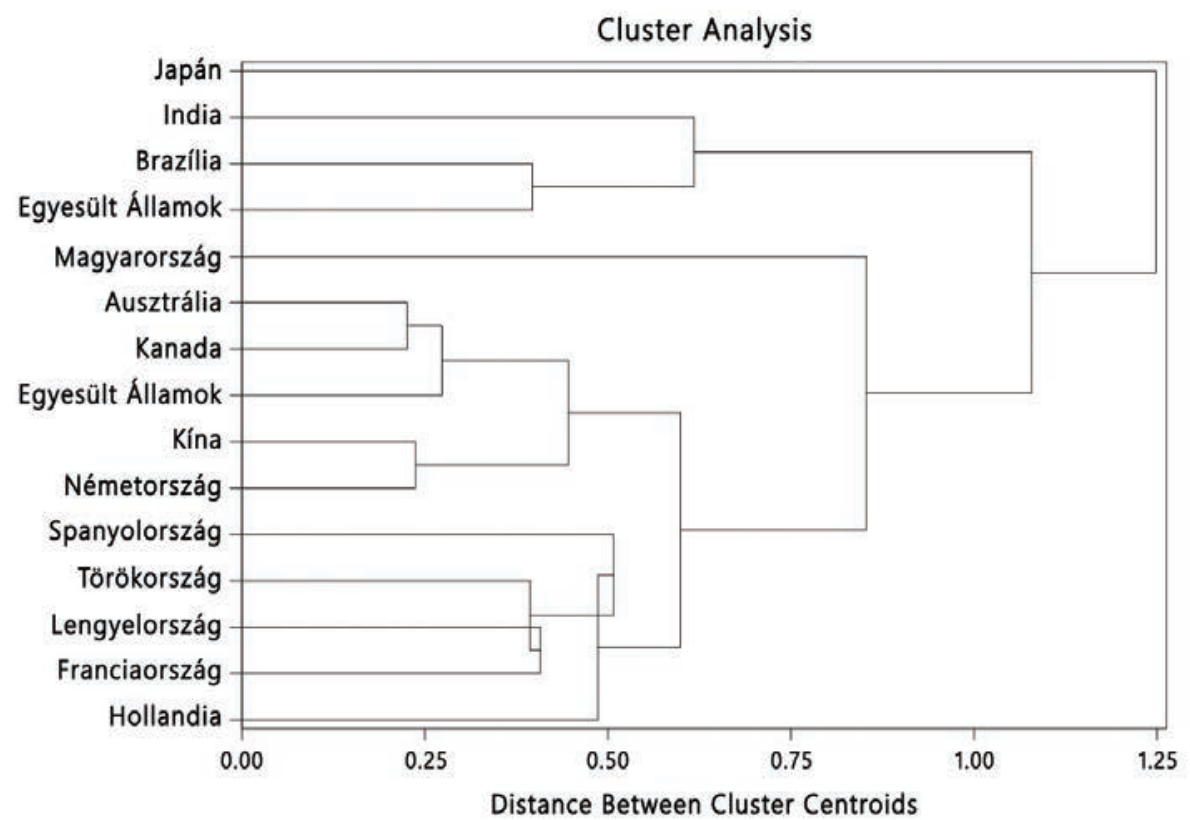

Forrás: saját számitás

A számítások alapján a következő országcsoportok rajzolódnak ki:

- India városi lakossága

- Brazília városi lakossága és az Egyesült Államok

- Ausztrália, Egyesült Királyság, Kanada, Kína városi lakossága és Németország

- $\quad$ Franciaország, Hollandia, Lengyelország, Spanyolország, Törökország városi lakossága

- Magyarország

- Japán

Az eredményeket a 2. sz. melléklet tartalmazza.

Miként jellemezhetők ezek az országcsoportok vizsgálatunk szempontjából?

India városi lakossága: Ők adták a legmagasabb pontszámokat szinte minden kérdésnél, különösen erős bennük a meggyőződés, hogy személyesen felelősek a nyugdíjukért, úgy érzik, hogy értik a pénzügyi folyamatokat, és a nyugdíjtervezéssel kapcsolatos ismereteket 
is pozitívan értékelték. Mindez nyilván nem független attól, hogy véleményük szerint nyugdijuknak csak 25 százaléka származik majd állami forrásból. Ez messze a legalacsonyabb érték a vizsgált országok közül, a következő Ausztráliában is 39 százalék.

Brazília városi lakossága és az Egyesült Államok: Erre a csoportra egy kérdés kivételével hasonló attitűdök és vélemények jellemzőek, mint Indiára. A kivétel a félretett pénz elégségességére vonatkozó kérdés: Míg az indiaiak 64 százaléka úgy véli, hogy elegendő vagy majdnem elegendő pénzt tesz félre, addig ebben a csoportban ez csak átlagosan 45 százalék.

Ausztrália, Egyesült Királyság, Kanada, Kína városi lakossága és Németország: Az, hogy ezek az országok egy csoportba kerültek, részben megfelel a sztereotípiáknak, hiszen az Egyesült Királyság és a vizsgált két volt „fehér gyarmat” jelenik meg itt, míg az a tény, hogy Németország inkább az itteni, mintsem az európai csoportba került, valamint a kínai és német válaszok hasonlósága talán szintén meglepő. Ezt a csoportot kisebb optimizmus jellemzi valamennyi kérdés esetében, mint az előzőt. A legnagyobb különbség a pénzügyi fogalmak ismeretére vonatkozó kérdésnél látszik, míg a brazil-amerikai csoport tagjainak 75 százaléka adott 4-5-öst magának, ebben a csoportban ez csak 61 százalék. Ezek a kevésbé optimista válaszok egyébként rendkívül közel vannak a teljes, 15 országos minta átlagához.

Franciaország, Hollandia, Lengyelország, Spanyolország, Törökország városi lakossága: Elözetes várakozásaimhoz képest itt is megfigyelhető két meglepetés. A mediterrán országokhoz csatlakozott Lengyelország, és nem Magyarországhoz hasonlít, valamint Hollandia nem Németországhoz, esetleg az Egyesült Királysághoz áll közel. A válaszok részletes vizsgálata azonban igazolni látszik a klaszterelemzés eredményeit. E csoport tagjai konzekvensen, minden kérdés esetében pesszimistább válaszokat adtak a kérdésekre, mint a teljes minta. Egy meglepő példa: a hollandok 23 százaléka úgy gondolja, hogy egyáltalán nem vagy csak kevéssé érti a nyugdíjtervezéssel kapcsolatos fogalmakat, ez az arány Németországban 8 százalék.

\section{Magyarország nem került be a mediterrán}

\section{közép-európai csoportba.}

Magyarország: Miért nem kerültünk be a mediterrán-közép-európai csoportba? Ez elsősorban három kérdésre adott nagyon pesszimista válaszunknak köszönhető. Egyrészt a személyes felelösséget firtató kérdésnél a válaszadók 19 százaléka egyáltalán nem vagy csak kismértékben érzi felelősnek magát a nyugdíjas évek jövedelméért (ez az előző országcsoportban 11\%), másrészt a nyugdijtervezésre irányuló ismereteinket is alacsonyabbra értékeltük. Ami pedig a már félretett pénz elégségességét illeti, a magyar válaszok a legpesszimistábbak a teljes mintában.

Japán: A Japánra vonatkozó eredmények értékeléséhez véleményem szerint mindenképpen figyelembe kell vennünk, hogy itt attitűdkutatásról van szó, tehát nem azt mutatják a számok, hogy egy adott ország lakossága mennyire felkészült a nyugdíjproblémák kezelésére, hanem azt, hogy ők hogyan értékelik a kérdést. A japán válaszadók személyes felelősségüket és a nyugdíjtervezési ismereteiket magasra értékelték, minden más kérdés esetében azonban sokkal alacsonyabb értékeket jelöltek be, mint a világátlag. Azt, hogy ez mennyire kulturálisan meghatározott (pl. nem illik magamról azt állítani, hogy valamiről a tudásom 5-ös), nem lévén a japán kultúra ismerője, nem tudom megítélni.

A jelentés összeállítói a fenti hat kérdés alapián egy szintetikus indexet állítottak elő (ARRI: Aegon Retirement Readiness Index). Ennek értékét mutatja az alábbi 2. ábra az eredeti országokra.

2. ábra: Nyugdíj-felkészültségi index változása

ARRI index változása

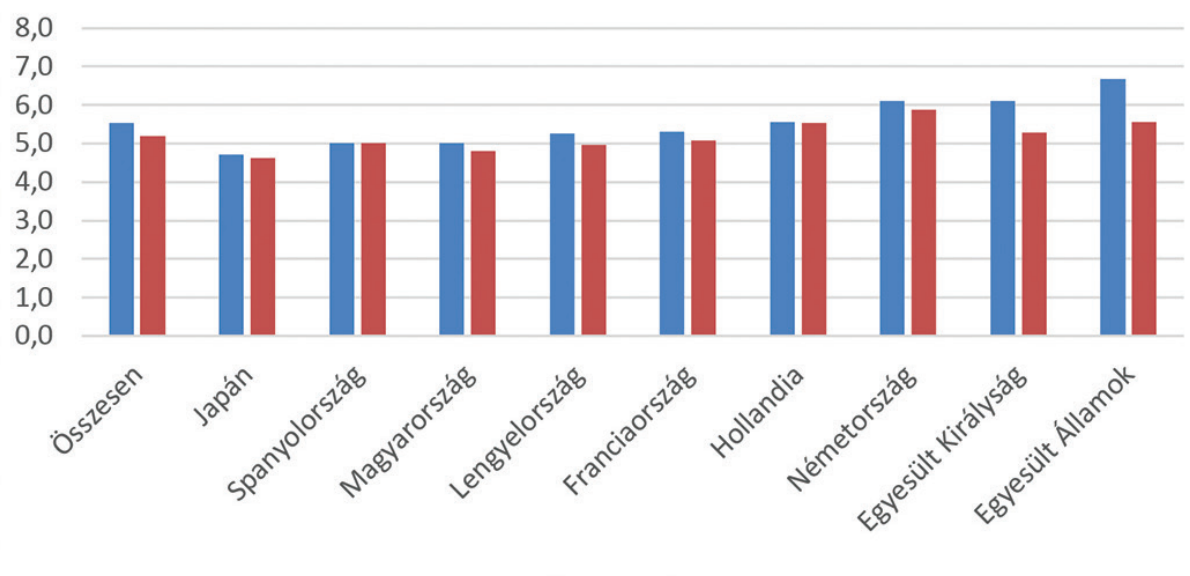

-2016 2012

Forrás: saját számitás

Mint látható, a felkészültségi index minden országban nőtt vagy stagnált, de jelentős változást csak az Egyesült Államokban, az Egyesült Királyságban és Lengyelországban látunk.

\section{Finanszírozás, adózás, nyugdíjkorhatár}

A kutatásban megkérdezték azt is, hogy a válaszadók szerint hogyan történjék a nyugdíjas évek finanszírozása? Itt értelemszerüen több választ is lehetett adni. A teljes minta válaszai a következők (az állítással nagyon vagy valamelyest egyetértők aránya):

- Az államnak kell gondoskodnia az emberekről a társadalombiztosításon keresztül: $75 \%$

- A munkáltatói nyugdíjprogramoknak kell juttatásokat biztosítaniuk: $72 \%$ 
- Az egyénnek kell gondoskodnia a saját nyugdíjáról privát nyugdíjbiztosítás vagy befektetés formájában: $62 \%$

- Azállamnak arra kell ösztönöznie a munkáltatókat, hogy minden munkavállalót automatikusan léptessenek be a nyugdíjprogramjukba: $75 \%$

- A nyugdíjak finanszírozása az egyén, a munkáltató és azállam közös felelőssége: 71\%

Az első három válasz alapján ismét elvégeztem az országok csoportokba sorolását, a dendrogrammot a 3. ábra tartalmazza.

3. ábra: Nyugdíj-finanszírozási országcsoportok

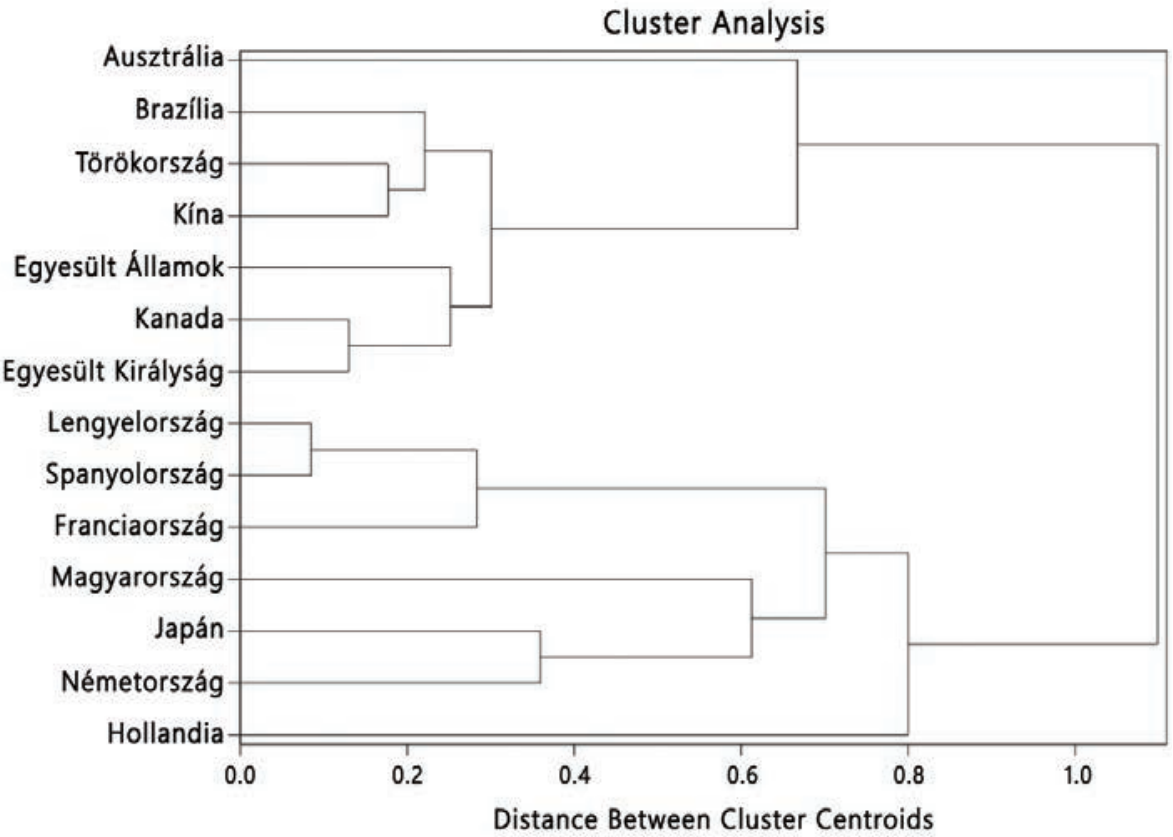

Forrás: saját számitás

Az országcsoportonkénti eredmények a 4 ábrán láthatók. Magyar szemmel talán a legérdekesebb eredmény, hogy bár az állami szerepről alkotott véleményünk alig haladja meg a teljes minta átlagát, mind a munkáltatónak, mind az egyénnek a magyarok szánják a legkisebb szerepet, ami különösen az egyéni szerepvállalás esetében elgondolkoztató.
4. sz. ábra: A nyugdíjas évek finanszírozása országcsoportonként

\section{Nyugdíjas évek finanszírozása}

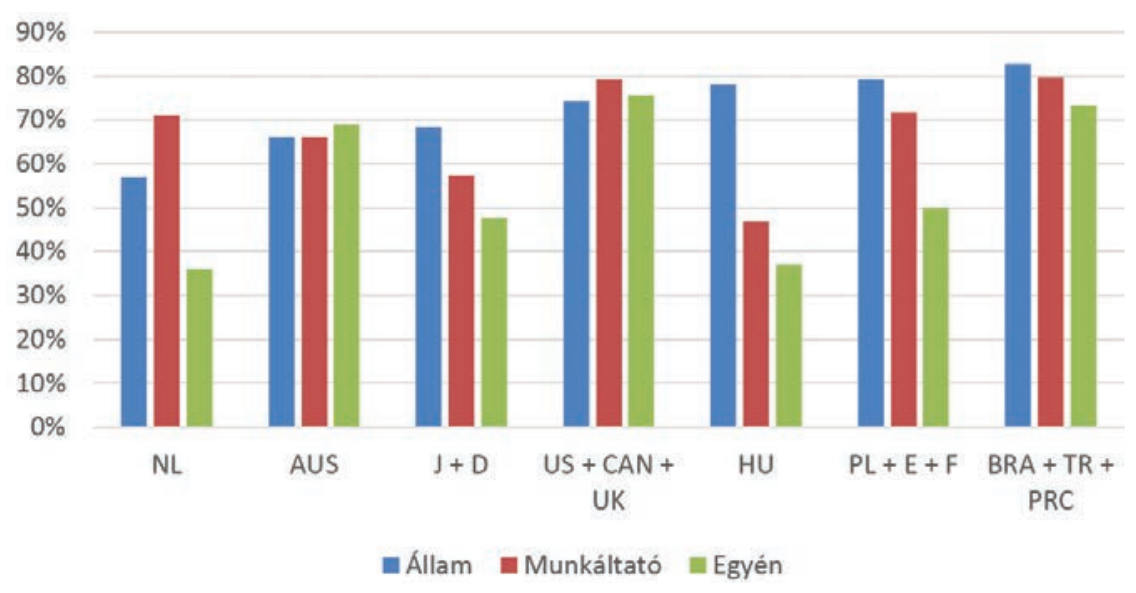

Forrás: saját számitás

Az utóbbi eredménynek látszólag ellentmond az, amit az 5. sz. ábrán látunk. E szerint a magyarok arra számítanak, hogy nyugdíjaskori jövedelmük 29 százalékát kell maguknak finanszírozniuk, ami nagyjából megfelel a teljes minta 30 százalékos átlagának. Az ellentmondást talán azzal oldhatjuk fel, hogy bár úgy tartanánk helyesnek, ha az egyénnek viszonylag csekély szerepe lenne a nyugdíj finanszírozásában, de azért tudjuk, hogy ez nem így van.

5. sz. ábra A várható nyugdíj forrása országonként

A nyugdíj forrása

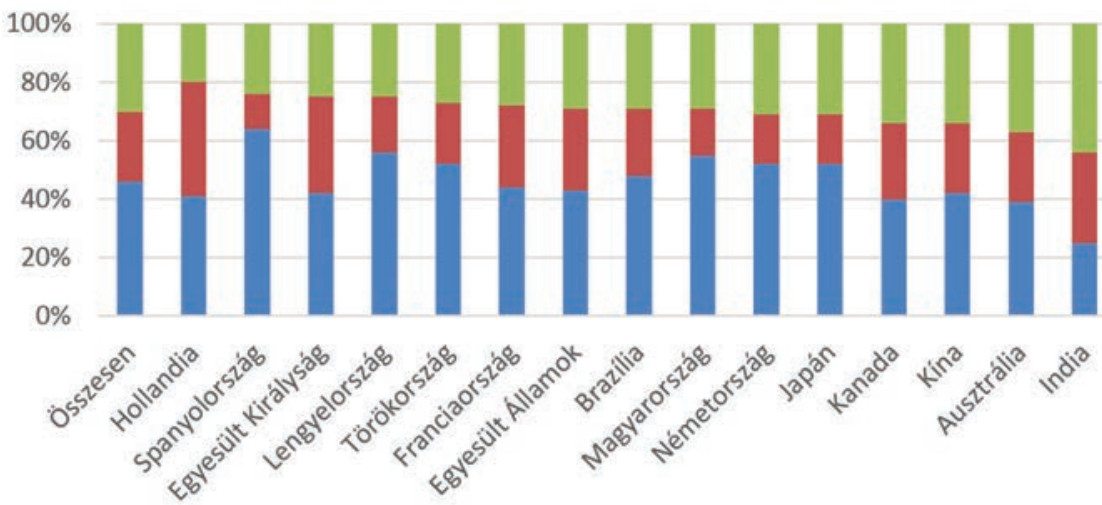

Forrás: saját számítós 
Mi tehát a teendő? Erre a következő válaszlehetőségeket ajánlották fel a megkérdezetteknek, zárójelben a teljes minta átlaga és a magyar érték.

- Az államnak csökkentenie kell a társadalombiztosítás kiadásait a nyugdíjak értékének csökkentésével, hogy ne kelljen növelni az adókat (15\%; 12\%).

- Az államnak adóemeléssel kell növelnie a társadalombiztosítás finanszírozását, hogy ne kelljen csökkenteni a nyugdíjak értékét (31\%; 41\%).

- Az államnak kiegyensúlyozott megoldást kell választania, csökkenteni minimálisan a nyugdíjak értékét, és kismértékben növelni az adókat (27\%; 19\%).

- Azállam ne tegyen semmit. A társadalombiztosítási ellátás tökéletesen finanszírozható lesz a jövőben is $(7 \%$; $3 \%)$

- $\quad$ Nem tudom $(20 \% ; 25 \%)$.

A „ne csináljunk semmit” válasz aránya az érdemi válaszadók között alacsony, 10 százalék körüli vagy az alatti, és éppen Magyarországon minimális (4\%). Ez alól érdekes módon két kivétel van: Hollandia (21\%) és Németország (13\%). Ugyanakkor a válaszadók jelentős része bevallja, hogy nincs véleménye a kérdésről, a legnagyobb arányban Franciaországban és Hollandiában (35\%,-33\%), míg ez az arány csak 8 százalék (!) Kínában.

Valamennyi országra igaz, hogy relatív többségben vannak vagy az adóemelés, vagy a kiegyensúlyozott megoldás hívei, ugyanakkor Magyarországon, Kínában és Spanyolországban az adóemelés hívei abszolút többségben vannak az érdemi válaszadók között. Ez érdekes módon ellentétes a gazdasági élet szereplőinek véleményével az élőmunka terheinek csökkentéséről.

A változtatások másik lehetséges módja a nyugdíjkorhatár emelése. Az erre vonatkozó válaszok (a zárójelben ismét a teljes minta, majd a magyar minta megoszlása):

- A nyugdijkorhatárt emelni kell a várható élettartam emelkedésével párhuzamosan (20\%; 14\%).

- A nyugdijkorhatárt emelni kell, kivéve azok esetében, akik veszélyes vagy fizikai munkát végeznek (18\%; 10\%).

- A nyugdíjkorhatárt emelni kell, de legyen egy felső határa (15\%; 8\%).

- A nyugdíjkorhatáron nem kell változtatni. Az emberek már így is sokáig dolgoznak (39\%; 63\%)

- $\quad$ Nem tudom $(8 \% ; 5 \%)$.
Magyarországon tehát a nyugdíjkorhatár emelését valamilyen formában elfogadók az érdemi válaszolók között alig 1/3-ot tesznek ki. Ezzel nálunk a legkisebb ez az arány, ezen kívül csak Németországban és a mediterrán országokban van kisebbségben ez a vélemény. Ezt a véleményt nyilván erősen befolyásolja, hogy éppen folyamatban van a nyugdíjkorhatár emelése. Az ellenkező végletet India városi lakossága és Japán jelenti, ahol ez az érték 80 százalék feletti. Érdemes ugyanakkor megjegyezni, hogy Indiában 60, Japánban 61 év mindkét nem esetében a nyugdíjkorhatár.

\section{Megtakarítási hajlandóság}

A kérdések kitértek a válaszolók megtakarítási hajlandóságára, 5 csoportot alakítva ki (a zárójelben lévő számok jelentése a szokásos: a teljes minta átlaga és a magyar érték)

- $\quad$ Rendszeres megtakarítók (38\%;25\%)

- Eseti megtakarítók (23\%; 17\%)

- A múltban megtakarítók (12\%; 13\%)

- Megtakarítani vágyók (21\%;35\%)

Nem megtakarítók $(6 \% ; 10 \%)$

A 6. sz. ábra az első három kategóriát összevonva, „Megtakarítók” jelzéssel tartalmazza.

6. sz. ábra: Megtakarítási hajlandóság országonként

Megtakarítási hajlandóság

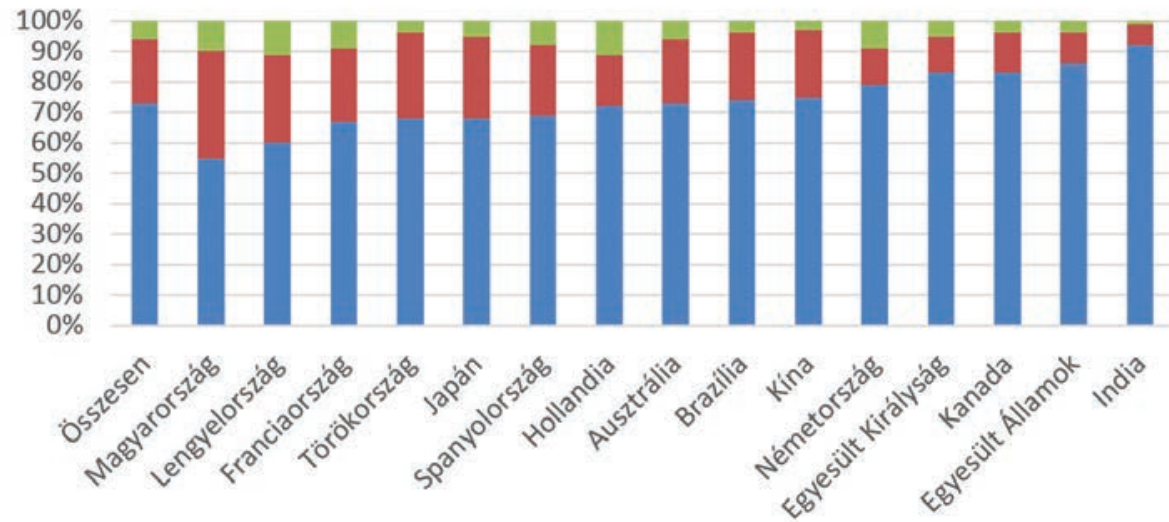

Forrás: saját számittás

Az eredmények elemzése erősen nemzetkarakterológiai irányba vihet, de azért jellemző lehet, hogy a mintában szereplő 5 mediterrán és közép-európai ország a megtakarítási hajlandóság szerinti lista utolsó 6 helyén szerepel. 


\section{Automatikus csatlakozás egy nyugdíjprogramhoz}

A kérdőív készítöi teszteltek egy olyan megoldást, ahol a munkáltató a jövedelem egy bizonyos százalékát automatikusan levonja a fizetésből, és átutalja egy nyugdijprogramba. Amennyiben ez a levonási arány 6 százalék, akkor a felmérésben részt vevők 65 százaléka egyetértene egy ilyen rendszerrel, és még 8 százalék levonása esetén is 61 százalékos az egyetértők aránya.

\section{Kell valamilyen külső kényszer, hogy hajlandóak legyünk \\ hosszú időre elhalasztani a fogyasztásunkat.}

A 6 százalékos esetben Japán (38\%) és Hollandia (49\%) kivételével minden országban többségben voltak a támogatók. Magyarországon 61 százalékos támogatást kapott az elképzelés. Úgy tünik, hogy a munkavállalók is érzik, kell valamilyen külső kényszer vagy automatizmus ahhoz, hogy hajlandóak legyünk extrém hosszú időre elhalasztani a fogyasztásunkat.

\section{Egyéni nyugdíjstratégiák}

E téma kapcsán a kutatók arra kérdeztek rá, hogy rendelkezik-e a munkavállaló végiggondolt nyugdíjtervvel, esetleg le is írta-e azt?

A válaszadók 58 százalékának van valamilyen terve (saját bevallásuk szerint!), az országok adatai 36 (Franciaország) és 84 százalék (India városi lakossága) között szóródnak, a magyar éppen az átlagos 58 százalék ${ }^{3}$.

A tervek természetesen függenek attól, hány éves korban szeretnénk nyugdíjba menni. A teljes minta átlaga 63 év, természetesen jelentős szórással, a munkavállalók 8 százaléka 50 éves kora előtt, egy másik 8 százalék viszont 70 éves kora után menne nyugdíjba. Legkorábban a fejlődő országok lakosai mennének nyugdíjba (55-60 év között), legtovább a hollandok dolgoznának, 67 éves korukig. A magyar adat megfelel az átlagnak.

A nyugdíjas évekre való felkészülés közben nem feledkezhetünk meg arról sem, hogy előfordulhatnak vészhelyzetek (pl. megrokkanás), amelyekre valamilyen vésztartalékkal kell rendelkeznünk. A megkérdezetteknek csak 32, Magyarországon 23 százaléka rendelkezik ilyen tartalékkal. A két véglet India városi lakossága (63\%) és Hollandia (19\%)

\section{Mit várunk a nyugdíjas évektől?}

A tanulmány egyik érdekes eredménye, hogy a munkavállalók 25 százaléka szeretne tovább dolgozni a nyugdíj mellett.
Ez az arány lényegesen magasabb Japánban, Indiában és Brazíliában (37\%; 39\%; 32\%), és sokkal alacsonyabb Franciaországban és Spanyolországban (15\%; 8\%).

A többi eredmény kevésbé meglepő, az utazás (60\%) és a barátokkal/családdal töltött idő (55\%) vezet.

Érdekes, hogy a nyugdíjra várók több mint 10 százaléka külföldre költözne nyugdíjaskorában, és ez az arány még a sokszor befelé fordulónak gondolt japánoknál is 7 százalék. A magyar adat 12 százalék.

\section{Összefoglaló magyar szemmel}

A kutatás, melynek adatai - mint már említettem - igazából önképet rögzítenek, a magyar válaszok sok esetben jelentősen eltértek a többségtől. A kialakuló kép nem túl pozitív.

A magyarok érzik legkevésbé a felelösségüket a nyugdíjas évek jövedelméért a vizsgált nemzetek közül, nyugdítervezésre irányuló ismereteiket is alacsonyra értékelik. Ugyanakkor mi érezzük leginkább úgy, hogy a nyugdíjra félretett pénz nem lesz elégséges. A nyugdíjfinanszírozásban ennek ellenére mind a munkáltatónak, mind az egyénnek a magyarok szánják a legkisebb szerepet.

\section{\A magyar válaszok sok esetben jelentősen eltértek a többségtől.}

Reálisan látjuk ugyan, hogy az állam és a munkáltatók együtt sem képesek kielégíteni a nyugdijigényeket, de a megtakarítók száma nálunk a legalacsonyabb. Mereven elutasítjuk a korhatáremelést mint eszközt, inkább támogatjuk a dolgozó korosztályok magasabb adóterhelését.

Mindez nem tűnik koherens képnek. Mivel a felmérésben egyetlen, hozzánk egyébként attitüd tekintetében a nemzetközi vizsgálatok szerint közel álló (balkáni) állam sem vett részt, így azt sem tudhatjuk, hogy mindez mennyire magyar sajátosság4. 


\section{IRODALOMJEGYZEK}

Ébresztő!! Készüljünk fel a nyugdij(unk)ra! Aegon Nyugdij-felkészültségi kutatás. Kézirat. 2016

Az egyes országok nyugdijkorhatáráról: Trading economics honlap: http://www.tradingeconomics.com/ (2016.08.22)

World Values Survey. Wave 6. http://www.worldvaluessurvey.org/WVSContents.jsp (2016.08.22.)

\section{HIVATKOZASOK}

oggal merül fel a kerdes, hogy ezt miért is kell(ene) a Szolvencia II Szolvencia I keretei között sem okozhatott volna „meglepetést” (persze amennyiben a megképzendö tartalékokat, pl. a várható

A „Havi fix” járadékbiztositási termék 2014. március 15-től hatályos Havi fix járadékbiztositás: Biztositási feltételek, ügyfél-tájékoztato" elnevezésú dokumentuma a biztosito honlapján elérhetö.

列

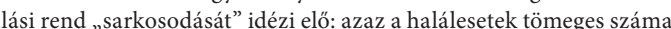
várhatóan egy későbbi szűkebb korintervallumra korlátozódik.

\section{MELLEKLETEK}

1.sz. melléklet

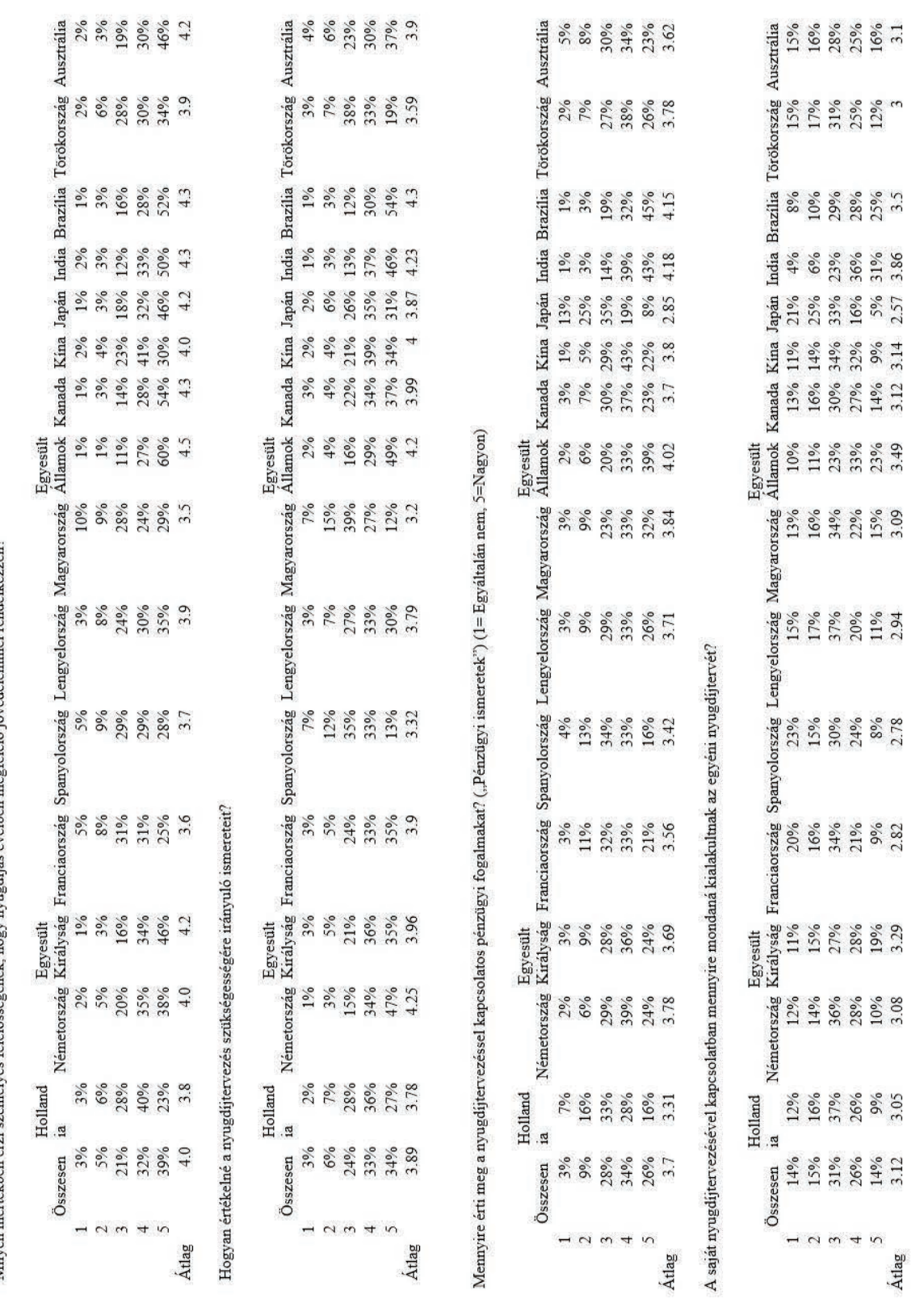




\begin{tabular}{|c|c|}
\hline 赵 & 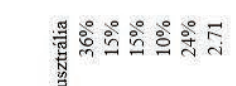 \\
\hline 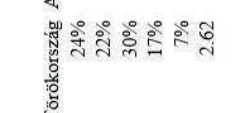 & 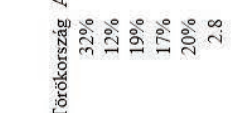 \\
\hline 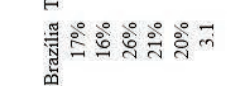 & 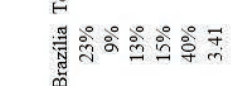 \\
\hline 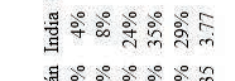 & 象 \\
\hline 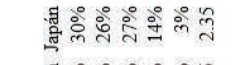 & 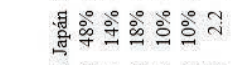 \\
\hline 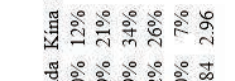 & 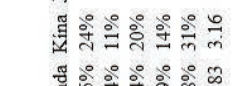 \\
\hline & \\
\hline 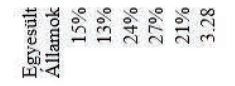 & 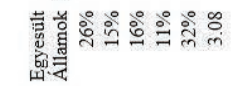 \\
\hline ำ & 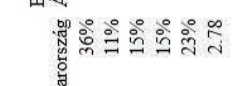 \\
\hline 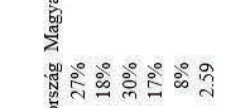 & 章 \\
\hline & \\
\hline 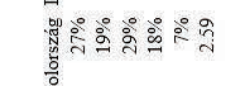 & 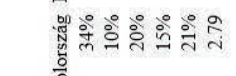 \\
\hline & \\
\hline 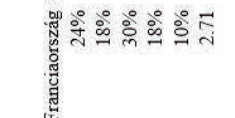 & 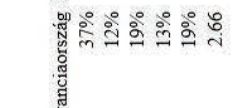 \\
\hline 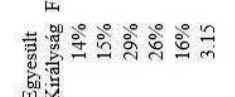 & 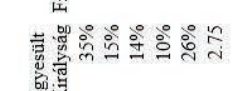 \\
\hline 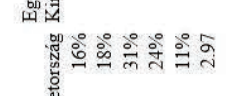 & 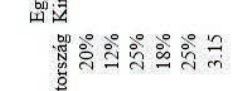 \\
\hline & \\
\hline 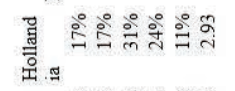 & 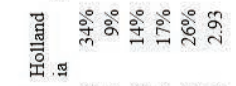 \\
\hline 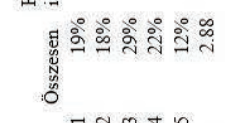 & 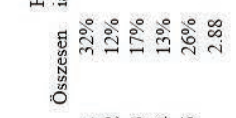 \\
\hline
\end{tabular}

2.sz. melléklet

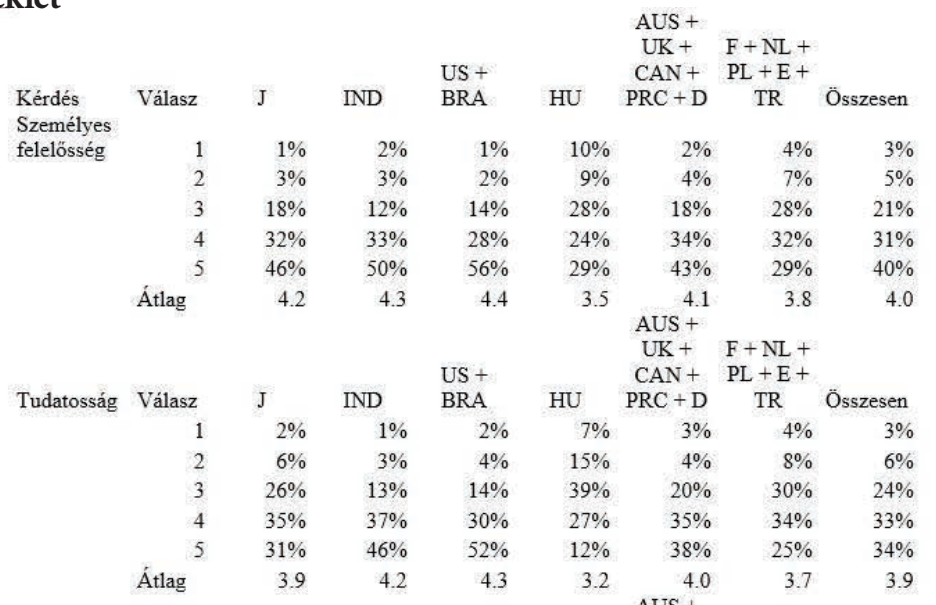

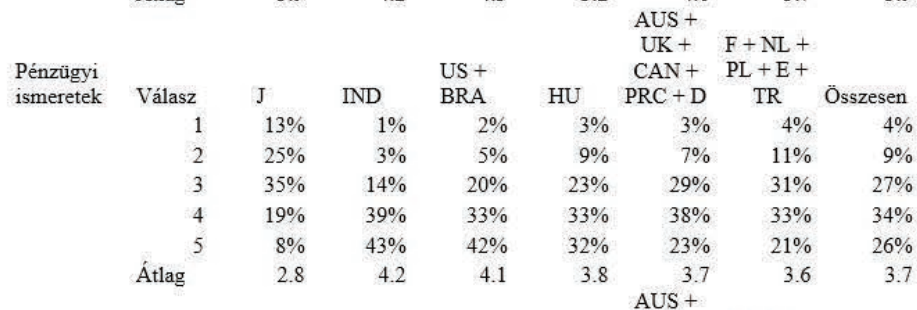

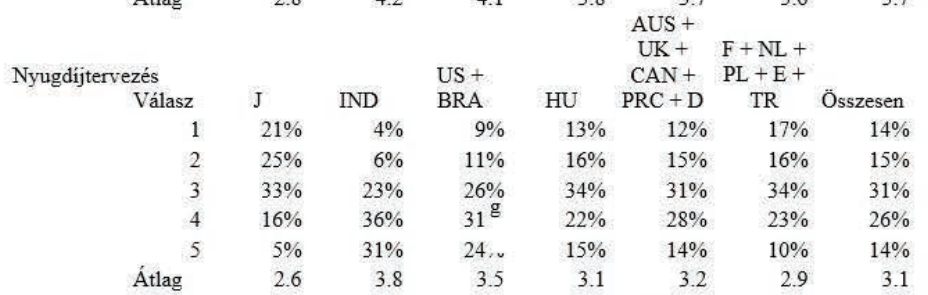

$\begin{array}{ll}\text { Pénzuigyi } & \text { AUS }+ \\ \text { felkésziltsés } & \mathrm{UK}+\mathrm{F}+\mathrm{NL}+\end{array}$

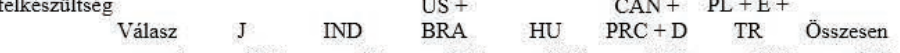
$\begin{array}{rrrrrrr}30 \% & 4 \% & 16 \% & 34 \% & 16 \% & 24 \% & 20 \% \\ 26 \% & 8 \% & 15 \% & 24 \% & 18 \% & 19 \% & 18 \% \\ 27 \% & 24 \% & 25 \% & 26 \% & 31 \% & 30 \% & 29 \% \\ 14 \% & 35 \% & 24 \% & 12 \% & 24 \% & 19 \% & 21 \% \\ 3 \% & 29 \% & 21 \% & 4 \% & 12 \% & 9 \% & 12 \% \\ 2.3 & 3.8 & 3.2 & 2.3 & 3.0 & 2.7 & 2.9\end{array}$

Átlag

$\mathrm{UK}+\mathrm{F}+\mathrm{NL}+$

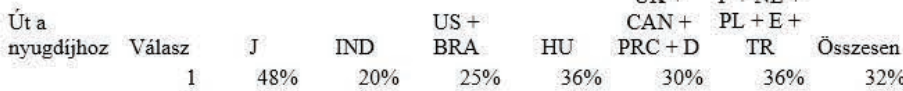
$\begin{array}{lllllll}48 \% & 20 \% & 25 \% & 36 \% & 30 \% & 36 \% & 32 \% \\ 14 \% & 15 \% & 12 \% & 11 \% & 13 \% & 11 \% & 13 \%\end{array}$

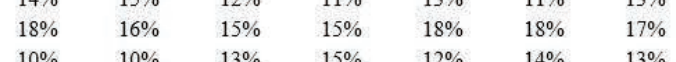

$\begin{array}{rrrrrrrr}5 & 10 \% & 39 \% & 36 \% & 23 \% & 27 \% & 20 \% & 25 \% \\ \text { Átlag }^{5} & 2.2 & 3.3 & 3.2 & 2.8 & 2.9 & 2.7 & 2.9\end{array}$ 